age. The initial values were, however, lower in those people with symptoms. Our findings agree on the whole with Fletcher's cbscrvations that an upper respiratory infection never caused a particularly rapid fall in F.E.V. A few of our patients with respiratory symptoms, however, showed a much greater drop in ventilatory capacity than the average subject, and a greater drop than any subject without any respiratory symptoms.

Our study thus confirms the observations of Fletcher and of Higgins et al. that cigarette smoking has a definite effect in decreasing the ventilatory capacity. Thus in Higgins $c t$ al.'s 25-34 age group the non-smokers showed a drop in F.E.V. $\cdot_{0.75}$ of 0.0211 . year, as opposed to a drop of 0.0371 . for the subjects smoking 1-14 g./day, $0.038 \mathrm{l}$. for the subjects smoking more than $15 \mathrm{~g}$./day, and 0.0291 . for the ex-smokers. The corresponding figures for their 55-64 age group were 0.032, 0.044, 0054 , and 0.037 1. Fletcher found a correlation between cigarette smoking and sputum eosinophilia, on the one hand, and an accelerated drop in F.E.V. on the other ; this was interpreted as increased bronchial "sensitivity" in some cigarette smokers. Thus smoking seems to worsen the pulmonary function whether or not the subject has respiratory symptoms. For example, Wilhelmsen and Tibblin (1966) found a significantly lower ventilatory capacity in heavy smokers having no respiratory symptoms than in non-smokers. The present study also points to a more rapid drop in ventilatory capacity among heavy smokers without chronic bronchitis than among nonsmokers and ex-smokers.

Hence these findings suggest that, in choosing control subjects, not only the absence of respiratory symptoms but also the smoking habits have to be considered. The cessation of smoking could not be shown to diminish ventilatory capacity significantly less than in those who still smoked, though there was a tendency in this direction. An improved ventilatory function after varying periods of non-smoking has been demonstrated by Krumholz et al. (1965), Wilhelmsen (1967), and Peterson et al. (1968).

\section{REFERENCES}

Berglund, E., et al. (1963). Acta Medica Scandinavica, 173, 185.

Carey, G. C. R Dawson, T. A. J., and Merritt, J. D. (1967). British fournal of Prcventive and Social Medicine, 21, 86.

Carey, G. C. R., Dawson, T. A. J., and Merrett, J. D. (1968). British Fournal of Preventive and Social Medicine, 22, 59.

Cotes, J. E., Rossiter, C. E., Higgins, I. T. T., and Gilson, J. C. (1966). British Medical fournal, 1, 1016.

Ferris, B. G., jun., Andersson, D. O., and Zickmantel, R. (1965). American Review of Respiratory Diseases, 91, 252.

Fletcher, C. M. (1968). fournal of the Royal College of Physicians of London, 2, 183.

Goldman, H. I., and Becklake, M. R. (1959). American Rcviєw of Tuberculosis and Pulmonary Diseases, 79, 457.

H:ggins, I. T. T., Gilson, J. C., Ferris, B. G., jun., Waters, M. E., Campbell, H., and Higgins, M. W. (1968). American fournal of Public Health, 58, 1667 .

Higgins, I. T. T., and Oldham, P. D. (1962). British fournal of Industrial Medicine, 19, 65.

Kory, R. C., Calahan, R., Boren, H. G., and Syner, J. C. (1961). American fournal of Medicine, 30, 243.

Krumholz, R. A., Chevalier, R. B., and Ross, J. C. (1965). Annals of Internal Medicine, 62, 197.

Medical Research Council's Committee on the Aetiology of Chronic Bronchitis (1965). Lancet, 1, 775.

Needham, C. D. Rogan, M. C., and McDonald, I. (1954). Thorax, 9, 313.

Pemberton, J., and Flanagan, E. G. (1956). Foumal of Applied Physio$\log y, 9,291$.

Peterson, D. I., Lonergan, L. H., and Hardinge, M. G. (1968). Archives of Environmental Health, 16, 215.

Ringqvist, T. (1966). Scandinavian fouinal of Clinical and Laboratory Investigation, Suppl. No. 88.

Welch, B. L. (1949. Biometrika, 36, 293.

Wilhelmsen, L. (1967). Scandinavian fournal of Respirato;y Discase, 48, 407.

Wilhelmsen, L. (1968). Acta Medica Scandinavica, Suppl. No. 489.

Wilhelmsen, L., and Tibblin, G. (1966). Scandinavian fournal of Respiratory Disease, 47, 121.

Wright, B. M., and McKerrow, C. B. (1959). British Medical fournal, 2, 1041 .

\title{
Exercise-induced Asthma
}

\author{
A. SEATON,* B.A., M.B., M.R.C.P. ; GLYN DAVIES, $\dagger$ B.SC., F.R.I.C. ; D. GAZIANO, $;$ M.D. \\ R. OSBORNE HUGHES, $\S$ M.B., B.SC., M.R.C.P.
}

British Medical fournal, 1969, 3, 556-558

Cummary : Tests in three patients with asthma occurring $\checkmark$ only on exertion showed ticat F.E.V. ${ }_{1}$ fell progressively on exercise, to reach a minimum after 10 minutes. Al! patients showed a striking metabolic acidosis, with an accumulation of the products of anaerobic metabolism.

\section{Introduction}

It is well known that exercise may induce bronchoconstriction in asthmatic subjects (Jones et al., 1962), and in some patients wheezing on exertion is the sole manifestation of illness (McNeill ct al., 1966 ; Crompton, 1968 ; Rebuck and Read, 1968). There is some uncertainty about the manner in which exercise produces bronchoconstriction, and to investigate this problem we have studied three patients with exercise-induced asthma.

\section{Techniques}

The patients were all studied in the same manner. All gave informed consent for these procedures. A Teflon cannula was introduced percutaneously into the radial or brachial artery and the patient was allowed to rest for a few minutes. The vital capacity and forced expiratory volume in one second
(F.E.V.) was then estimated by a pulmometer (Godart) on three occasions and a control arterial blond sample was taken. This and all subsequent samples were analysed for $\mathrm{pH}, \mathrm{PCO}_{2}$, $\mathrm{Po}_{2}$, lactate, and pyruvate. $\mathrm{pH}$ was measured by a Radiometer capillary electrode, $\mathrm{PCO}_{2}$, with a Severinghaus electrode, and the Sigaard-Andersen nomogram was used for calculation of base excess and standard bicarbonate. Po., was measured with an EIL Bishop electrode. The arterial blood was analysed enzymatically for lactate and pyruvate (Bochringer kits) and excess lactate was calculated from Huckabee's (1958a) equation as $(\mathrm{Ln}-\mathrm{Lo})-(\mathrm{Pn}-\mathrm{Po})(\mathrm{Lo} / \mathrm{Po})$, where $\mathrm{Lo}$ and $\mathrm{Po}$ are initial and $\mathrm{Ln}$ and $\mathrm{Pn}$ subsequent concentrations of lactate and pyruvate respectively in millimoles per litre. The patient was then asked to hyperventilate until he felt tingling in his fingers. A second arterial sample was obtained and three further cstimations of F.E.V., were made. When his F.E.V., and blood gases had returned to normal the patient rebreathed $5 \%$ carbon dioxide in oxygen for five minutes and a further arterial sample and measurements of F.E.V..$_{1}$ were obtained.

\footnotetext{
* Senior Medical Registrar.

+ Biochemist.

$\neq$ Rescarch Fcllow.

Regional Pulmonary Function Laboratory, Broadgrecn Hospital, Liverpool 14.
}

$\S$ Medical Registrar, Royal Infirmary, Livirpool 3. 
After a further period of rest a baseline arterial sample and F.E.V. ${ }_{1}$ were obtained and the patient was exercised by running for five to eight minutes. At the end of exercise serial arterial samples and measurements of F.E.V.. were obtained until the patient recovered.

\section{Patients}

Clinical details and resting pulmonary function tests are summarized in Tables I and II.

Cases 1 and 3 had no previous history of allergic or chest disease, nor was there any such illness in their families. Both had a history of increasingly troublesome wheezing on exertion for about five years. Case 2 gave no history of allergic or respiratory illness, but two of his cousins were asthmatic. His symptoms had gradually worsened since they started three years ago. All three patients had normal chest radiographs, and Cases 1 and 3 had normal resting pulmonary function tests. The three patients, however, had a mild hypoxia at rest, though in all cases this was corrected by hyperventilation. Case 2 in addition had a mild hypercapnia and slight overinflation of the lungs (residual volume $125 \%$ of normal).

\section{Results}

Effect of Hyperventilation (Table III).-Hyperventilation was associated with a fall in F.E.V. of 1 litre in Case 1 and of 0.5 litre in Case 3 but with no change in Case 2. All three patients showed a profound respiratory alkalosis. At the same time there was an appreciable rise in lactate in Cases 1 and 3, but very little rise in Case. 2.

Effect of Rebreathing Carbon Dioxide (Table IV).-The F.E.V. ${ }_{1}$ rose slightly in Case 2, but there was no change in the other two patients. A definite respiratory acidosis and increased minute volume occurred during the period of rebreathing in all three patients.

Effect of Exercise (Table V and Chart).-In a preliminary test the three patients were exercised by gentle running until they were mildly dyspnoeic. All showed a progressive fall in F.E.V., after exercise and did not return to normal for more than two hours in spite of injections of adrenaline.

On the second test, carried out some weeks later, the F.E.V. again reached a minimum about 10 minutes after exercise. On this occasion the arterial blood analyses were carried out. In

Table I.-Clinical Details of Patients

\begin{tabular}{|c|c|c|c|c|c|c|c|c|c|c|}
\hline \multirow{2}{*}{$\begin{array}{l}\text { Case } \\
\text { No. }\end{array}$} & \multirow{2}{*}{ Sex } & \multirow{2}{*}{ Age } & \multicolumn{2}{|c|}{ Height } & \multicolumn{2}{|c|}{ Weight } & \multirow{2}{*}{ Occupation } & \multirow{2}{*}{ Smoking History } & \multirow{2}{*}{$\begin{array}{c}\text { Duration } \\
\text { of } \\
\text { Illness }\end{array}$} & \multirow{2}{*}{$\begin{array}{c}\text { Family } \\
\text { History } \\
\text { of Asthma }\end{array}$} \\
\hline & & & ft. in. & $\mathrm{m}$. & lb. & kg. & & & & \\
\hline $\begin{array}{l}1 \\
2 \\
3\end{array}$ & $\begin{array}{l}\text { Male } \\
\text { Male } \\
\text { Male }\end{array}$ & $\begin{array}{l}45 \\
42 \\
44\end{array}$ & $\begin{array}{ll}5 & 5 \\
6 & 2 \\
5 & 9\end{array}$ & $\begin{array}{l}1.65 \\
1.88 \\
1.75\end{array}$ & $\begin{array}{l}150 \\
182 \\
182\end{array}$ & $\begin{array}{l}68 \cdot 0 \\
82 \cdot 6 \\
82 \cdot 6\end{array}$ & $\begin{array}{l}\text { Commercial traveller } \\
\text { Contractor } \\
\text { Fireman }\end{array}$ & $\begin{array}{l}\text { Nil } \\
\text { Occasional cigar } \\
\text { Nil }\end{array}$ & $\begin{array}{l}4 \text { years } \\
5 \text { years } \\
5 \text { years }\end{array}$ & $\begin{array}{l}\text { No } \\
\text { Yes } \\
\text { No }\end{array}$ \\
\hline
\end{tabular}

Tablle II.-Resting Pulmonary Function Tests

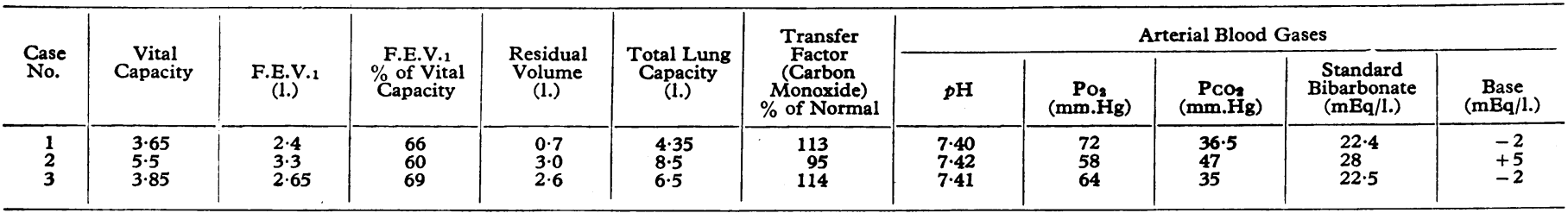

TABLE III.-Response to Hyperventilation

\begin{tabular}{|c|c|c|c|c|c|c|c|c|c|}
\hline $\begin{array}{l}\text { Case } \\
\text { No. }\end{array}$ & $\begin{array}{c}\text { Change } \\
\text { in F.E.V.1 } \\
\text { (1.) }\end{array}$ & $p H$ & $\underset{(\mathrm{mm} \cdot \mathrm{Hg})}{\mathrm{Po}_{\mathbf{g}}}$ & $\underset{(\mathrm{mm} \cdot \mathrm{Hg})}{\mathrm{PcO}_{2}}$ & $\begin{array}{c}\text { Standard } \\
\text { Bicarbonate } \\
(\mathrm{mEq} / \mathrm{l} .)\end{array}$ & $\underset{(\mathrm{mEq} / 1 .)}{\text { Base }}$ & $\begin{array}{c}\text { Rise in } \\
\text { Lactate } \\
\text { (mMoles/1.) }\end{array}$ & $\begin{array}{c}\text { Rise in } \\
\text { Pyruvate } \\
\text { (mMoles/1.) }\end{array}$ & $\begin{array}{c}\text { Excess } \\
\text { Lactate } \\
\text { (mMoles/1.) } \\
\end{array}$ \\
\hline $\begin{array}{l}1 \\
2 \\
3\end{array}$ & $\begin{array}{l}\text { Fell } 1.0 \\
0 \\
\text { Fell } 0.5\end{array}$ & $\begin{array}{l}7.65 \\
7 \cdot 65 \\
7 \cdot 68\end{array}$ & $\begin{array}{l}90 \\
90 \\
86\end{array}$ & $\begin{array}{l}17 \cdot 5 \\
17 \cdot 5 \\
15 \cdot 5\end{array}$ & $\begin{array}{l}24 \cdot 2 \\
23 \cdot 4 \\
23 \cdot 5\end{array}$ & $\begin{array}{l}+0.3 \\
-0.5 \\
-0.5\end{array}$ & $\begin{array}{l}0.76 \\
0.14 \\
0.41\end{array}$ & $\begin{array}{l}0.042 \\
0.008 \\
0.01\end{array}$ & $\begin{array}{l}+0.39 \\
+0.15 \\
+0.37\end{array}$ \\
\hline
\end{tabular}

TABLE IV.-Response to Hypercapnia

\begin{tabular}{|c|c|c|c|c|c|c|c|c|c|c|}
\hline $\begin{array}{l}\text { Case } \\
\text { No. }\end{array}$ & $\begin{array}{l}\text { Change } \\
\text { in F.E.V.1 } \\
\text { (1.) }\end{array}$ & $p \mathrm{H}$ & $\underset{(\mathrm{mm} . \mathrm{Hg})}{\mathrm{Pog}_{\mathbf{g}}}$ & $\underset{(\mathrm{mm} . \mathrm{Hg})}{\mathrm{PcO}_{\mathbf{2}}}$ & $\begin{array}{c}\text { Standard } \\
\text { Bicarbonate } \\
(\mathrm{mEq} / 1 .)\end{array}$ & $\underset{(\mathrm{mEq} / 1 .)}{\text { Base }}$ & $\begin{array}{c}\text { Fall in } \\
\text { Lactate } \\
\text { (mMoles/1.) }\end{array}$ & $\underset{\begin{array}{c}\text { Fall in } \\
\text { (mMruvate } \\
\text { Myoles/1.) }\end{array}}{\text {. }}$ & $\begin{array}{c}\text { Excess } \\
\text { Lactate } \\
(\mathrm{mMoles} / 1 .)\end{array}$ & $\begin{array}{l}\text { Minute Volume } \\
\text { (Last Two } \\
\text { Minutes) (1.) }\end{array}$ \\
\hline $\begin{array}{l}1 \\
2 \\
3\end{array}$ & $\begin{array}{l}0 \\
+0 \cdot 25 \\
0\end{array}$ & $\begin{array}{l}7 \cdot 28 \\
7 \cdot 23 \\
7 \cdot 26\end{array}$ & $\begin{array}{l}164 \\
116 \\
159\end{array}$ & $\begin{array}{l}60 \\
57 \\
55\end{array}$ & $\begin{array}{l}23 \cdot 3 \\
20 \cdot 5 \\
21 \cdot 5\end{array}$ & $\begin{array}{l}-0.8 \\
-4 \\
-3\end{array}$ & $\begin{array}{l}0.29 \\
0.1 \\
0.25\end{array}$ & $\begin{array}{l}0 \\
0 \\
0.006\end{array}$ & $\begin{array}{l}-0.04 \\
+0.05 \\
0\end{array}$ & $\begin{array}{l}30 \\
28 \\
30\end{array}$ \\
\hline
\end{tabular}

TABLE V.-Effect of Exercise

\begin{tabular}{|c|c|c|c|c|c|c|c|c|c|c|}
\hline & & & $\underset{(1 .)}{\text { F.E.V.1 }}$ & $p \mathrm{H}$ & $\underset{(\mathrm{mm} . \mathrm{Hg})}{\mathrm{Po}_{\mathbf{2}}}$ & $\underset{(\mathrm{mm} \cdot \mathrm{Hg})}{\mathrm{Pcos}}$ & $\underset{(\mathrm{mEq} / 1 .)}{\text { Base }}$ & $\begin{array}{c}\text { Lactate } \\
\text { (mMoles/1.) }\end{array}$ & $\begin{array}{c}\text { Pyruvate } \\
\text { (mMoles/1.) }\end{array}$ & $\begin{array}{c}\text { Excess } \\
\text { Lactate } \\
(\mathrm{mMoles} / 1 .)\end{array}$ \\
\hline $\begin{array}{l}\text { Before exercise } \quad \ldots \\
\text { Immediately after exercise } \\
10 \text { minutes after exercise }\end{array}$ & $\because$ & $\because$ & $\begin{array}{l}2 \cdot 5 \\
1 \cdot 25 \\
0 \cdot 8\end{array}$ & $\begin{array}{l}7 \cdot 38 \\
7 \cdot 17 \\
7 \cdot 21\end{array}$ & $\begin{array}{l}{ }^{\text {Case } 1} \\
69 \\
42\end{array}$ & $\begin{array}{l}41 \\
44 \\
39 \cdot 5\end{array}$ & $\begin{array}{l}-0.9 \\
=13 \\
-11 \cdot 8\end{array}$ & $\begin{array}{l}1 \cdot 43 \\
9 \cdot 77 \\
7 \cdot 83\end{array}$ & $\begin{array}{l}0.171 \\
0.33 \\
0.332\end{array}$ & $\begin{array}{l}-0.07 \\
+6.88 \\
+4.92\end{array}$ \\
\hline $\begin{array}{l}\text { Before exercise } \ldots \\
\text { Immediately after exercise } \\
10 \text { minutes after exercise }\end{array}$ & $\because$ & $\because$ & $\begin{array}{l}3 \\
3 \cdot 5 \\
1 \cdot 6\end{array}$ & $\begin{array}{l}7 \cdot 41 \\
7 \cdot 28 \\
7 \cdot 38\end{array}$ & $\begin{array}{l}47^{\text {Case } 2} \\
64 \\
47\end{array}$ & $\begin{array}{l}33 \cdot 5 \\
29 \cdot 5 \\
30\end{array}$ & $\begin{array}{l}-3 \\
=12 \\
-6.5\end{array}$ & $\begin{array}{l}0.65 \\
5 \cdot 61 \\
3 \cdot 72\end{array}$ & $\begin{array}{l}0 \cdot 072 \\
0 \cdot 286 \\
0 \cdot 256\end{array}$ & $\begin{array}{l}+0 \cdot 04 \\
+4 \cdot 85 \\
+2 \cdot 98\end{array}$ \\
\hline $\begin{array}{l}\text { Before exercise } \\
\text { Immediately after exercise } \\
\text { 10|minutes after exercise }\end{array}$ & $\begin{array}{l}. \\
\cdots\end{array}$ & $\because$ & $\begin{array}{l}3 \\
2 \cdot 7 \\
1 \cdot 6\end{array}$ & $\begin{array}{l}7 \cdot 46 \\
7 \cdot 32 \\
7 \cdot 31\end{array}$ & $\begin{array}{l}\text { Case } 3 \\
64 \\
88 \\
64\end{array}$ & $\begin{array}{l}30 \\
30 \\
30 \cdot 5\end{array}$ & $\begin{array}{l}-2 \\
-9 \cdot 5 \\
-10\end{array}$ & $\begin{array}{l}0.49 \\
7.05 \\
5.79\end{array}$ & $\begin{array}{l}0 \cdot 087 \\
0 \cdot 24 \\
0 \cdot 35\end{array}$ & $\begin{array}{r}+0.14 \\
+6.09 \\
+4.39\end{array}$ \\
\hline
\end{tabular}


all patients there was a striking metabolic acidosis with considerable accumulation of products of anaerobic metabolism as evidenced by the high excess lactate. As the acidosis began to improve, so, after a 10-minute time lag, did the F.E.V.. (see Chart). In Case 3, when the F.E.V. fell to half its resting level, the acidosis was corrected by intravenous injection of $50 \mathrm{mEq}$

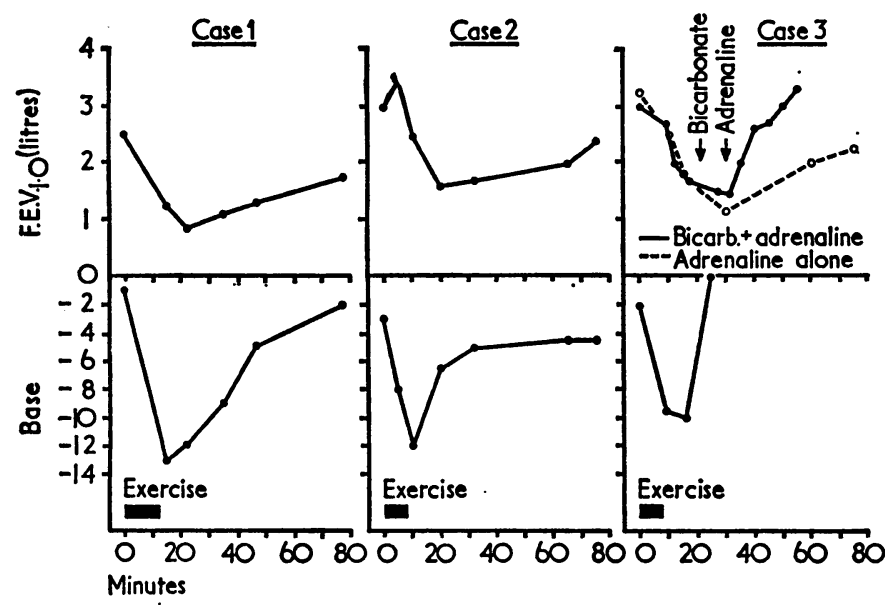

Effect of exercise on F.E.V.1 and arterial base.

of sodium bicarbonate solution. This was followed by the subcutaneous injection of $0.3 \mathrm{ml}$. of $1 / 1,000$ adrenaline. On this occasion the F.E.V. rose to its resting level within 20 minutes, whereas in the preliminary test without bicarbonate there had been no response to adrenaline. Subsequently, Case 2 was shown to respond similarly to bicarbonate and adrenaline.

At the end of exercise, all three patients had a higher $\mathrm{Po}_{2}$ than before exercise and two of the patients had slight hypocapnia. When the wheeze developed all three patients showed a fall in $\mathrm{Po}_{2}$. Case 1 was subsequently exercised after intravenous bicarbonate. Though he showed no arterial acidosis immediately after exercise, he developed bronchoconstriction as in the previous tests and subsequently developed an arterial base deficit of -5 .

\section{Discussion}

The condition of exercise-induced asthma has been described surprisingly infrequently in adults (McNeill, 1965; McNeill et al., 1966 ; Crompton, 1968 ; Rebuck and Read, 1968). These patients are probably latent asthmatics in whom exercise produces the only stimulus to bronchoconstriction (Jones and Jones, 1966). It is well known that bronchoconstriction may be produced in asthmatic subjects by exercise (Jones et al., 1962) and that this effect may be blocked by prior administration of sympathomimetics, steroids (Jones et al., 1963), and disodium cromoglycate (Davies, 1968). Once bronchoconstriction has been initiated, however, it is usually unresponsive to pharmacological agents, as in our three patients (Sly et al., 1967 ; Rebuck and Read, 1968).

The precise cause of the bronchoconstriction after exertion is not understood. Any theory must take into account the response to drugs mentioned above, the time relationship to exercise, and the delay of two hours before recovery is complete. In addition, the diminishing effect of repeated exercise over the course of a day (McNeill et al., 1966), the absence of any bronchoconstriction after hyperventilation induced by rebreathing, and the occasional fall in F.E.V..$_{1}$ on voluntary hyperventilation must be explained.

The onset of bronchoconstriction shortly after exercise is consistent with release of a humoral substance. Body stores of such a substance may become depleted and therefore repeated exercise would cause a smaller effect, as suggested by McNeill et al. (1966). It seems unlikely that hyperventilation per se caused the bronchoconstriction in our patients, as appeared to be the case with Crompton's (1968) patient, because of the delay in onset after the maximal ventilation of exercise and our patients' inability to produce bronchoconstriction of any severity by hyperventilation. The alternative possibility that hypocapnia caused the bronchoconstriction appears unlikely, as the very low $\mathrm{PCO}_{2}$ produced by voluntary hyperventilation was associated with a smaller effect on F.E.V..$_{1}$. Hypoxia did not seem to play any part in initiating bronchoconstriction in our patients, appearing only after the patient had started to wheeze.

The most consistent finding in the three patients was a striking metabolic acidosis. It is possible that this acts as a trigger at a cellular level to release either directly or indirectly a substance such as bradykinin or SRS-A and thus to initiate bronchoconstriction. It is known that the reaction producing bradykinin from its precursor is dependent on an enzyme and that maximum accumulation of bradykinin takes place when the reaction occurs at a low $\mathrm{pH}$ (Brocklehurst, 1967 ; Lewis, 1968).

Acidosis may also have the effect of blocking the action of sympathomimetics, as is known to occur in patients in status asthmaticus (Blumenthal et al., 1956; Mithoefer et al., 1965). In this case the acidosis, though primarily respiratory, probably has a large metabolic component owing to the considerable work of respiration against a background of hypoxia (Huckabee, $1958 \mathrm{~b})$. On the basis of this reasoning, correction of the metabolic acidosis should make patients with exercise-induced asthma amenable to conventional bronchodilator therapy, and this appeared to be the case in the patients in whom we tested this theory. We were unable, however, to prevent the bronchoconstriction in one patient by prevention of arterial acidosis. In these circumstances it is nevertheless impossible to prevent the production of acid metabolites by the cells, and it is presumably at this level that the effect of $\mathrm{pH}$ is important.

The accumulation of acid products of metabolism occurs not only on exertion but also as a compensatory response to respiratory alkalosis (Huckabee, 1958a). This could account for the mild bronchoconstriction occurring after hyperventilation in two of our patients.

We are grateful to Drs. E. Wyn Jones, J. Emlyn Jones, and D. Leeming for allowing us to publish details of patients under their care, to Dr. C. M. Ogilvie for help in the preparation of this paper, and to Miss Susan Williams for technical help.

\section{REFERENCES}

Blumenthal, J. S., Brown, E. B., and Campbell, G. S. (1956). Annals of Allergy, 14, 506.

Brocklehurst, W. E. (1967). In Modern Trends in Immunology-2, edited by R. Cruickshank and D. M. Weir. London, Butterworths. Crompton, G. K. (1968). Thorax, 23, 165.

Davies, S. E. (1968). British Medical fournal, 3, 593.

Huckabee, W. E. (1958a). Fournal of Clinical Investigation, 37, 244

Huckabee, W. E. (1958b). Fournal of Clinical Investigation, 37, 264.

Jones, R. H. T., and Jones, R. S. (1966). British Medical fournal, 2,

Jones, R. S., Buston, M. H., and Wharton, M. J. (1962). British fournal of Diseases of the Chest, 56, 78.

Jones, R. S., Wharton, M. J., and Buston, M. H. (1963). Archives of Disease in Childhood, 38, 539.

Lewis, G. P. (1968). Fournal of the Royal College of Physicians of London, 2, 353.

McNeil, R. S.'(1965). Thorax, 20, 285.

McNeill, R. S., Nairn, J. R., Millar, J. S., and Ingram, C. G. (1966) Quartorly fournal of Medicine, 35, 55 .

Mithoefer, J. C., Runser, R. H., and Karetzky, M. S. (1965). New England fournal of Medicine, 272, 1200

Rebuck, A. S., and Read, J. (1968). Lancet, 2, 429.

Sly, R. M., Heimlich, E. M., Busser, R. J., and Strick, L. (1967). Fournal of Allergy, 40, 93. 